\title{
The Effect of Earning Management on Level of Stickiness Cost in Registered Consumer Goods Industry Sector Companies on the Indonesia Stock Exchange 2016-2018
}

\author{
Heni Fajariwati*, Nurafni Eltivia, Riezky Amalia \\ Accounting Department \\ State Polytechnic of Malang \\ Malang, Indonesia \\ *hennyfajar33@gmail.com
}

\begin{abstract}
The purpose of this research is to identify whether SG\&A costs are sticky and analyze whether earning management practices can reduce the level of stickiness costs. The population of this research is the consumer goods industry sector companies listed on the Indonesia Stock Exchange in 2016-2018. Samples were selected using purposive sampling technique, with a total sample used were 25 companies. The analysis model used was multiple linear regression processed using SPSS version 25. This research found that SG\&A costs increased by 1.077 percent when sales increased by 1 percent. Meanwhile, when sales fell by 1 percent, SG\&A costs decreased by $\mathbf{- 0 . 0 4 0 7}$ percent. The results of this research also show that earning management can reduce the level of stickiness cost by upward earning management practices.
\end{abstract}

Keywords - component, stickiness cost, earning management, discretionary accrual, $S G \& A$ cost

\section{INTRODUCTION}

Management accounting is concerned with providing information to managers, namely the people within the organization who direct and control the organization's operations [1].

Information that managers can get from management accounting is past cost behavior patterns. Cost information is important information because this information can assist managers in predicting costs more accurately regarding future costs to make more effective and efficient cost planning as well as in decision making. Managers who understand cost behavior are better at predicting what will happen to the cost flow in several operating situations, and make it easier for activity planning [2].

In carrying out its operational activities, the company is inseparable from the problem of costs, both production costs and non-production costs that are incurred so that these products are sold for sale. In the traditional model, costs are defined as fixed costs and variable costs related to the level of change in the volume of activity. In general, it is assumed that the variable cost changes proportionally to the level of change in the volume of activity.

Meanwhile, fixed costs are constantly unchanged and have no effect on the level of change in the volume of activity. The traditional cost behavior assumes that the rate of change in costs is proportional to the level of activity, and fixed costs and variable costs associated with changes in volume of activity are symmetrical for volume to decrease and volume to increase. However, what actually happens is that the cost behavior is asymmetrical, where there are costs that tend to be rigid when there is an increase or decrease in activity.

The movement of costs is said to be disproportionate because the amount of increase in costs caused by an increase in activity volume is greater than the amount of cost reduction due to a decrease in activity volume, and this condition is known as stickiness cost [3]. Thus, when sales decrease while costs are fixed (sticky), then the profit earned by the company will be reduced (low). In addition, stickiness cost behavior can also reduce the level of accuracy in forecasting earnings [4].

According to Jin, the motivation for earning management has a significant impact on reducing the level of stickiness costs in companies registered in China [5]. The perspective of earning management can help managers to estimate the level of stickiness costs in the company more accurately, so that it makes management in making company decisions more precise and encourages increased company performance. Agency theory implies the existence of information asymmetry between managers and shareholders. This condition provides an opportunity for managers to use the information they know to manipulate financial reporting and practice earning management.

This study aimed to test the presence of stickiness on the company's cost consumer goods industry sector, can reduce the 
stickiness cost forecasting accuracy rate of profit, so that stickiness may also cause errors in cost decision, therefore stickiness cost must be prevented so that the company not to losess. In addition, this study also aims to determine whether earning management can reduce the level of stickiness costs.

\section{THEORETICAL REVIEW}

\section{A. Stickiness Cost}

The behavior of cost changes implemented in cost accounting is actually asymmetrical (proportional) characterized by the rigidity of costs when a decrease in activity occurs, contrary to the theory of the nature of activity volume and cost changes which are said to be symmetrical. The existence of this imbalance is assumed to occur due to a decrease in costs that are lower than the volume of activity that comes from a decrease in the volume of activity, a situation like this is called stickiness costs [3].

Stickiness cost occurs due to imbalance adjustment of resources, that is, it is slower in a decreasing adjustment process than an increasing adjustment process. When demand increases, the manager decides to increase production capacity, so that the cost element will also increase and cause the cost of goods sold to increase. However, when demand decreases, managers will minimize production costs, but not all costs will decrease symmetrically following production activities.

The stickiness cost sales, general and administration (SG\&A) behavior occurs when managers decide to keep unused resources compared to adjusting costs when the volume of demand decreases. Research on stickiness costs uses SG\&A costs as a measure in determining the stickiness cost behavior that appears in the company.

According to Xue and Hong there are two main viewpoints regarding the existence of stickiness costs, namely rational and motivational decision making [6]. The point of view of rational decision making sees stickiness cost as a result of rational management decisions by considering alternatives after considering costs and benefits comprehensively. The second point of view is motivational based and connects stickiness costs with managerial incentives, which means that managers do not need to behave rationally or encourage managers to behave dysfunction ally (deviating) from the task they should be doing.

\section{B. Earning Management}

Earning management is a management activity aimed at getting more profits or vice versa that is reported at that time without an increase or decrease in the company's long-term financial profitability. Meanwhile, earning management is an intervention from managers who refer to financial reporting for outsiders to provide personal benefits, according to Na'im \& Setiawati [7]. This is one of the causes that encourages a reduction in credibility in financial reporting [8].
From the previous statement, it can be drawn a final line that refers to earning management, which is a management activity that is carried out deliberately in manipulating profits or leading to a desired level of profit to achieve certain goals.

\section{Agency Theory}

When linked with agency theory, the reason for managers to practice earning management can be related to an opportunistic point of view, namely differences in ownership and company management that can lead to 2 problems, namely information asymmetry and conflict of interest. The agent will want to maximize their needs by getting as much bonus as possible opportunistically while the principal will try to increase the profitability. The different interests of the two parties have resulted in an urge to prioritize each other's interests. Internal parties have direct contact with the entire performance of the entity, so that their dependence on the company's accounting information is not as great as external parties.

\section{HYPOTHESIS}

\section{A. The existence of Stickiness Cost in the Consumer Goods Industry Sector Companies}

Costs do not change proportionally with changes in activities due to imbalance adjustment of resources, causing stickiness costs to occur. The main cause of stickiness costs is the uncertainty about the future demand of the products sold by the company which causes managers to tend to choose to keep unused resources rather than reduce resources when sales decline. However, if managers choose to adjust the costs incurred, stickiness costs will not occur [9]. SG\&A costs represent a significant proportion of business operating costs [10]. Based on this explanation, the following hypothesis can be formulated:

$\mathrm{H} 1=\mathrm{SG} \& \mathrm{~A}$ costs in the consumer goods industry sector companies listed on the Stock Exchange in 2016-2018 are sticky.

\section{B. Earning Management Ability to Reduce Level of Stickiness Cost}

Based on research by Hong and Xue [6], Jin [5] and Martania [3], earning management has a significant impact on reducing the level of stickiness costs in companies. The perspective of earning management can help managers to estimate the level of stickiness costs in the company more accurately, so that it makes management in making company decisions more precise and encourages increased company performance.

Managers have an incentive to manage costs to avoid losses and various other reasons, earning management incentives will affect the company's cost behavior. Based on the description above, the following hypothesis is formulated: 
$\mathrm{H} 2$ = Upward earning management can reduce the level of stickiness cost of consumer goods industry sector companies listed on the IDX in 2016-2018.

\section{RESEARCH METHODS}

The research object used in this research is the consumer goods industry sector companies listed on the Indonesia Stock Exchange during 2016-2018. Based on the sampling criteria and using purposive sampling, there are 25 companies in the consumer goods industry sector that meet the requirements for completeness and data needs in this study.

The population and research sample were taken based on purposive sampling technique, namely the sampling method was not random and only met certain criteria or conditions that could be used as a research sample.

The dependent variable used in this study is the SG\&A cost as a proxy for stickiness cost. This study compares SG\&A costs for a certain period $(\mathrm{t})$ with $\mathrm{SG} \& \mathrm{~A}$ costs for the previous period $(\mathrm{t}-1)$ using the following formula:

$$
\left[\frac{S G \& A_{i, t}}{S G \& A_{i, t-1}}\right]
$$

Meanwhile, the independent variables used in this study are net sales, net sales dummy and discretionary accruals. The independent variable is a variable that has a major influence on other variables or affected variables. The following is an explanation of each independent variable:

\section{A. Net Sales}

Net sales are used as a proxy for sales volume. The value of a certain period's net sales (t) will be compared with the previous period's net sales period (t-1) using the following formula [9]:

$$
\text { Net sales }=\left\lceil\frac{N S_{i, t}}{N S_{i t-1}}\right\rceil
$$

\section{B. Net sales dummy}

The net sales dummy is a variable that multiplies the dummy value and the comparison of net sales in period $t$ with net sales in period $\mathrm{t}-1$. The following is the formula for these variables [9]:

$$
\text { Net sales dummy }=\text { Dummy } y_{i, t} *\left\lceil\frac{N S_{i, t}}{N S_{i t-1}}\right\rceil
$$

If company $i$ experiences an increase in net sales, then the net sales dummy will be worth 0 , if company $i$ experiences a decrease in net sales it will be worth 1 .

\section{Discretionary Accruals}

DA value is a proxy for earning management obtained from calculations based on the Modified Jones Model. The following is the formula for discretionary accruals [9]:
Discretionary accruals $=$ Dummy $y_{i, t} *\left[\frac{P B_{i, t}}{P B_{i, t-1}}\right] * D A$

The analytical tool in this study uses multiple linear regression because it has more than one variable. The analysis procedure begins with a classical assumption test, then tests the first and second hypotheses. There are two regression equation models in this study. To test the existence of stickiness cost, this study uses the regression equation model owned by Anderson et al., [9]. Here is the regression equation model:

$$
\begin{gathered}
\log \left[\frac{S G \& A_{i, t}}{S G \& A_{i, t-1}}\right]=\beta_{0}+\beta_{1} \log \left[\frac{N S_{i, t}}{N S_{i, t-1}}\right] \\
\quad+\beta_{2} \text { Dummy } * \log \left[\frac{N S_{i, t}}{N S_{i, t-1}}\right]+\varepsilon_{i, t}
\end{gathered}
$$

If net sales have increased, the dummy value will be 0 , while the dummy value will be 1 if the situation is the opposite. Since the dummy value is 0 when net sales increase, the coefficient $\beta 1$ shows the percentage increase in SG\&A costs every $1 \%$ increase in net sales. Meanwhile, the dummy value will change to 1 when net sales have decreased, so that the sum of the coefficients $\beta 1$ and $\beta 2$ shows the percentage of cost reduction every $1 \%$ decrease in net sales. If SG\&A costs are sticky, the percentage increase must be greater than the percentage decrease. Thus, the basis for $\mathrm{H} 1$ is:

$$
\beta 1>0 ; \beta 2<0
$$

Furthermore, to test the ability of earning management to reduce the level of stickiness costs, the equation model used is that of Farzaneh et al. [11]. The following is the regression equation model:

$$
\begin{aligned}
& \log \left[\frac{S G \& A_{i_{j}, t}}{S G \& A_{i_{j}, t-1}}\right]=\beta_{0}+\beta_{1} \log \left[\frac{P B_{i_{1, t}}}{P B_{i_{j} t-1}}\right] \\
& +\beta_{2} \text { Dummy } * \log \left[\frac{P B_{i, t}}{P B_{i, t-1}}\right]+ \\
& \beta_{a} \text { Dummy } * \log \left[\frac{P B_{i, t}}{P B_{i, t-1}}\right] * D A+\varepsilon_{i, t}
\end{aligned}
$$

Just like the previous equation, if net sales have increased, the dummy value will be 0 , while the dummy value will be 1 if the situation is the opposite. If upward earning management can reduce the level of stickiness costs at SG\&A costs, then the coefficient $\beta 2$ must be negative and $\beta 3$ must be positive. Thus, $\mathrm{H} 2$ is:

$\beta 1$ and $\beta 3>0 ; \beta 2<0$

\section{RESUlTS AND ANALYSIS}

To determine the existence of stickiness costs in consumer goods industrial sector companies in Indonesia, as well as to 
determine whether earning management is able to reduce the level of stickiness costs, first, this study conducted a descriptive statistical analysis of hypotheses one and two. Descriptive statistical analysis provides an overview of the maximum value, minimum value, average value (mean) and standard deviation of the variables studied. Second, performing a classic assumption test consisting of normality, multicollinearity, heteroscedasticity and autocorrelation tests before testing hypotheses one and two, this is done to determine whether the data is suitable for analysis or not, because not all data can be re-analyzed. Then, based on the test results show that the two regression equation models have passed the classical assumption test. Furthermore, this study uses the regression equation model from Anderson et al., to test hypothesis one [9]. The results of testing hypothesis one are as follows Table 1:

TABLE I. HyPOTHESIS TEST ResUlts 1

\begin{tabular}{|l|l|l|}
\hline \multirow{2}{*}{ Model } & \multicolumn{2}{c|}{$\begin{array}{c}\text { Unstandardized } \\
\text { Coefficients }\end{array}$} \\
\cline { 2 - 3 } & \multicolumn{1}{|c|}{$\boldsymbol{B}$} & Std. Error \\
\hline (Constant) & .001 & .007 \\
\hline Penjualan bersih & 1.077 & .169 \\
\hline Dummy penjualan bersih & -1.484 & .425 \\
\hline
\end{tabular}

The first hypothesis testing in this study is determined using the coefficients $\beta 1$ and $\beta 2$. The value of the coefficient $\beta 1$ shows the percentage increase in SG\&A costs due to an increase in net sales of $1 \%$. Meanwhile, the sum of the coefficients $\beta 1$ and $\beta 2$ shows the percentage of cost reduction due to a decrease in net selling costs by $1 \%$. Hypothesis one is proven true if, $\beta 1$ has a positive sign and $\beta 2$ has a negative sign. Based on table 1, it can be seen that the coefficient value $\beta 1>0$ is 1.077 and the coefficient value $\beta 2<0$ is -1.484 . In addition, through table 1 it can be seen the amount of increase and decrease in SG\&A costs.

Every $1 \%$ increase in net sales will increase SG\&A costs by 1,077 , whereas every $1 \%$ decrease in net sales will decrease SG\&A costs by $(1,077-1,484)-0.407 \%$. Thus, it can be concluded that hypothesis one is accepted because the percentage increase is greater than the percentage decrease, or in other words, SG\&A costs for consumer industry sector companies listed on the IDX in 2016-2018 are sticky, along with research conducted by Martania [3], Xue and Hong [6] and Wahyuningtyas and Nugrahanti [12] indication of stickiness cost behavior at SG\&A costs.

TABLE II. HyPOTHESIS TEST RESUlTS 2

\begin{tabular}{|l|l|l|}
\hline \multirow{2}{*}{\multicolumn{1}{|c|}{ Model }} & \multicolumn{2}{c|}{$\begin{array}{c}\text { Unstandardized } \\
\text { Coefficients }\end{array}$} \\
\cline { 2 - 3 } & \multicolumn{1}{|c|}{ B } & Std. Error \\
\hline (Constant) & .003 & .010 \\
\hline Penjualan bersih & 1.098 & .215 \\
\hline Dummy penjualan bersih & -1.137 & .272 \\
\hline DA & .046 & .096 \\
\hline
\end{tabular}

Source: Data processed by SPSS
Based on table 2 , the value of the coefficient of $\beta 1, \beta 2$ and $\beta 3$ coefficient determine the truth of the hypothesis of the two proposed in this study. The value of the coefficient $\beta 1$ shows the percentage increase in SG \& A costs on a $1 \%$ increase in net sales. Meanwhile, the sum of the $\beta 1, \beta 2$ and $\beta 3$ coefficients shows the percentage reduction in SG\&A costs at $1 \%$ decrease in net sales due to the practice of upward earning management in the company. Hypothesis two is proven true if $\beta 1$ and $\beta 3$ are positive, $\beta 2$ is negative.

Based on tabel 2, it can be concluded that upward earning management can reduce the level of stickiness cost, because the coefficient value $\beta 1>0$ is 1.098 , the coefficient value $\beta 2<0$ is -1.137 , and the coefficient value $\beta 3>0$ is 0.046 . Meanwhile, every $1 \%$ increase in net sales will increase SG\&A costs by $1.098 \%$ and the practice of upward earning management will reduce SG\&A costs by $0.007 \%$ for every $1 \%$ decrease in net sales. Thus, it can be concluded that the second hypothesis is accepted because the practice of upward earning management can reduce the level of stickiness costs, in line with the research of Hong \& Xue [6], Jin [5] and Martania [3], earning management has a significant impact on reducing the level of stickiness costs in companies.

\section{CONCLUSION AND SUGGESTION}

Based on the research results, it can be concluded that there is an indication of sticky cost behavior at SG\&A costs. The increase in SG\&A costs when sales are up is greater than the decrease in SG\&A costs when sales are down. This is due to the tendency of managers to keep resources idle when sales decline. Furthermore, based on the research results show that the practice of upward earning management can reduce the level of stickiness cost at SG\&A costs. This can occur because of the manager's motivation to avoid losses and decrease profits.

Suggestion of this research is first, this research uses an opportunistic perspective, it is better if further research can use other perspectives, for example an informational perspective. Second, the dependent variable used as a proxy for stickiness cost in this study is the SG\&A cost, preferably for further research using other variables, such as production costs. Third, this study uses the method of measuring accrual earnings management (discretionary accruals), it is better if further research uses the method of real earnings management approach (abnormal cash flow operations, abnormal production costs and abnormal discretionary expenses), because it is considered to be able to capture the real effect better than just accrual operation.

\section{REFERENCES}

[1] R. Garrison, E. Noreen, and P. Brewer, "Akuntansi Manajerial, Buku Dua,” Jakarta: Salemba Empat, 2008.

[2] E. Susilo, “Analisis Perilaku Sticky Cost dan Pengaruhnya Terhadap Prediksi Laba Menggunakan Model Cost Variability dan Cost Stickiness (CVCS) Pasda Emiten di BEI Untuk Industri Manufaktur," Akad. Akunt. Keuang. dan Perbank. Indones., vol. 2, no. 2, 2016. 
[3] R.M. Martania, N. Eltivia, and M.A. Setiawan, "Apakah Earnings Management MampuMengurangi Tingkat Stickiness Cost," J. Riview Akunt. dan Keuang., vol. 8, pp. 125-134, 2018.

[4] D. Weiss, "Cost behavior and analysts' earnings forecasts," Account. Rev., vol. 85, no. 4, pp. 1441-1471, 2010.

[5] Y. Jin, "Does Earnings Management Affect the Cost Stickiness of Corporate?," 2017.

[6] S. Xue and Y. Hong, "Earnings management, corporate governance and expense stickiness," China J. Account. Res., vol. 9, no. 1, pp. 41-58, 2016.

[7] L. Setiawati and A. Na'im, "Manajemen laba," J. Indones. Econ. Bus., vol. 15 , no. 4, pp. 424-441, 2000.

[8] A.U. Widyaningdyah, "Analisis faktor-faktor yang berpengaruh terhadap earnings management pada perusahaan go public di Indonesia," J. Akunt. dan Keuang., vol. 3, no. 2, pp. 89-101, 2001.
[9] M.C. Anderson, R.D. Banker, and S.N. Janakiraman, "Are selling, general, and administrative costs 'sticky'?," J. Account. Res., vol. 41, no. 1, pp. 47-63, 2003.

[10] C.X. Chen, H. Lu, and T. Sougiannis, "The agency problem, corporate governance, and the asymmetrical behavior of selling, general, and administrative costs," Contemp. Account. Res., vol. 29, no. 1, pp. 252 $282,2012$.

[11] N. Farzaneh, S. Javad, S. Mahdi, and B.S. Ali Haddad, "A Study Of The Stickiness Of Cost Of Goods Sold And Operating Costs To Changes In Sales Level In Iran.," Stud. Bus. Econ., vol. 8, no. 2, 2013.

[12] L. Ratnawati and Y.W. Nugrahanti, "Perilaku Sticky Cost Biaya Penjualan, Biaya Administrasi dan Umum Serta Harga Pokok Penjualan Pada Perusahaan Manufaktur," J. Ekon. dan Bisnis, vol. 18, no. 2, pp. 65-80, 2015. 